\title{
К. М. Логановський
}

Державна установа «Національний науковий центр радіаційної медицини Національної академії медичних наук України», вул. Мельникова, 53, м. Київ, 04050, Україна

\section{ПАТОЛОГІЧНИЙ РОЗВИТОК ОСОБИСТОСТІ ПІСЛЯ ЧОРНОБИЛЬСЬКОЇ КАТАСТРОФИ ТА АНТИТЕРОРИСТИЧНОЇ ОПЕРАЦІї}

Метою дослідження було визначення патологічних змін особистості в учасників ліквідації наслідків аварії (УЛНА) на Чорнобильській АЕС (ЧАЕС) і в учасників антитерористичної операції (АТО) на Сході України та оцінка особливостей сприйняття радіаційної загрози.

Дизайн, об'єкт та методи дослідження. Проведена поперечна і ретроспективна оцінка УЛНА на ЧАЕС ( $n=185)$, евакуйованих осіб з Чорнобильської зони відчуження $(n=112)$ із рандомізованої вибірки осіб, які знаходяться на обліку в Клініко-епідеміологічному реєстрі (КЕР) Державної установи «Національний науковий центр радіаційної медицини Національної академії медичних наук України [ННЦРМ] та учасників АТО $(n=62)$, які проходили лікування і реабілітацію у відділенні радіаційної психоневрології клініки ННЦРМ. Використовувались клінічні нейропсихіатричні і психометричні методи: опитувальник загального здоров'я (General Health Questionnaire, GHQ-28), особистісний опитувальник Г. Айзенка (Eysenck Personality Inventory EPI), методика діагностики характерологічних особливостей Г. Шмишека - К. Леонгарда, та модифікований соціально-психологічний опитувальник (Joint Study Project 1993) - «анкета небезпек».

Результати. Виявлено зниження екстраверсії, гіпертимності та демонстративності в УЛНА на ЧАЕС та евакуйованих, а також збільшення емотивності, педантичності, тривожності, циклотимності, збудливості та дистимності. В учасників АТО знизилась екстраверсія та гіпертимність, зросли застрягання, педантичність, циклотимність, збудливість та дистимність. При аналізі результатів соціально-психологічного опитувальника («анкети небезпек») було виявлено, що актуальний на даний момент фактор «національні конфлікти» займає серед УлНА 22ге рангове місце, серед евакуйованих - 18-те, в той час як серед учасників АТО - 11-те, однак сприйняття ризику отримати хворобу пов'язану з наявністю в оточуючому середовищі радіоактивних речовин учасники АТ0 поставили на 6-те місце, УЛНА - на 8-ме, евакуйовані - на 7-ме. Гіпертрофоване сприйняття радіаційної загрози в УЛНА та евакуйованих корелює з підвищенням занепокоєння з приводу атомної промисловості ( $<<0,001)$; ступенем психологічного стресу від Чорнобильської катастрофи $(p<0,001)$, ступенем психологічного стресу від евакуації $(p<0,01)$, із занепокоєнням щодо впливу радіації на здоров'я $(p<0,001)$, негативними соціальними та економічними змінами в зв'язку з Чорнобильською катастрофою $(p<0,001)$. Учасники AT0 не довіряють компетенції осіб, які відповідають за події на Сході України (46,3\%), при цьому доволі сильно занепокоєні майбутнім (48,8 \%) та недоброзичливим ставленням до себе $(25,0 \%)$.

Висновки: В усіх групах досліджуваних спостерігаються ознаки загострення характерологічних рис та збільшення кількості акцентуацій особистості. В учасників АТО відбувається формування фрустраційного патологічного розвитку особистості, яке об'єднує соціально-стресові, посттравматичні стресові та психосоматичні розлади. Гіпертрофоване сприйняття радіаційного ризику притаманне всім групам обстежених.

Ключові слова: антитерористична операція, акцентуації характеру, сприйняття радіаційної загрози, фрустрація, учасники ліквідації аварії на ЧАЕС.

Проблеми радіаційної медищини та радіобіології. 2016. Вип. 21. С. 247-263.

Логановський Костянтин Миколайович, e-mail: loganovsky@windowslive.com 


\section{K. M. Loganovsky $\bullet$, M. V. Gresko}

State Institution «National Research Center for Radiation Medicine of the National Academy of Medical Sciences of Ukraine», 53 Melnykova Street, Kyiv, 04050, Ukraine

\section{Pathological personality development after the Chornobyl disaster and the anti-terrorist operation}

Objective of the study was to determine pathological changes of the personality of the clean-up workers (liquidators) of the Chornobyl accident and the participants in the anti-terrorist operation (ATO) in Eastern Ukraine and radiation threat perception assessment.

Design, object and methods. The cross-sectional and retrospective assessments of the clean-up workers of the Chornobyl accident $(n=185)$, evacuees from the Chornobyl Exclusion Zone $(n=112)$ from the randomized sample of individuals who are registered in the Clinical and epidemiological registry (CER) of the State Institution «National Research Center for Radiation Medicine of National Academy of Medical Sciences of Ukraine» [NRCRM] and participants of the ATO in Eastern Ukraine $(n=62)$ who underwent treatment and rehabilitation in the Department of Radiation Psychoneurology of the NRCRM Clinic have been done. The neuropsychiatric clinical and psychometric methods as General Health Questionnaire, GHQ-28; Eysenck Personality Inventory, EPI; method of personality diagnostic by H. Schmischek - K. Leongard, and modified social-psychological questionnaire (Joint Study Project 1993) - «dangers questionnaire» were used.

Results. Extraversion, hyperthymia and demonstrativity in the clean-up workers of the Chornobyl accident and evacuees decreased, while emotiveness, pedantry, anxiety, cyclothymia, excitability and dysthymia increased. Extraversion and hyperthymia decreased in the ATO participants while jams, pedantry, cyclothymia, excitability and dysthymia increased. According to the social-psychological assessment («dangers questionnaire») there were found that at present the «national conflict» factor takes among the clean-up workers the $22^{\text {th }}$ rank place, evacuees - the $18^{\text {th }}$, while the participants ATO - the $11^{\text {th }}$, however the risk perception of disease associated with the presence in the environment of radioactive substances in the ATO participants takes the 6 th place, the liquidators - the $8^{\text {th }}$, the evacuees - the $7^{\text {th }}$. Hypertrophic radiation threat perception in the clean-up workers and evacuees correlates with increasing concern about the nuclear industry $(p<0.001)$; the degree of psychological stress related to the Chornobyl disaster $(p<0.001)$; the degree of psychological stress of evacuation $(p<0.01)$; with concern of radiation impact on health $(p<0.001)$; negative social and economic changes due to the Chornobyl disaster $(p<0.001)$. The ATO combatants do not trust to the competence of those responsible for the events in Eastern Ukraine $(46.3 \%)$, while quite strongly concerned about the future $(48.8 \%)$ and hostile attitude to themselves $(25.0 \%)$.

Conclusions. There are signs of personality exacerbation/maladjustment and personality accentuation increasing in all studied groups. In ATO combatants the pathological personality development of frustration is forming, that social-stress, post-traumatic stress and psychosomatic disorders integrates. Hypertrophic radiation risk perception is inherent in all groups surveyed.

Key words. Anti-terrorist operation, accentuation of character, perception of radiation threat, frustration, clean-up workers (liquidators) of the Chornobyl accident.

Problems of radiation medicine and radiobiology. 2016;21:247-263.

\section{ВСТУП}

Медичні та соціально-психологічні наслідки Чорнобильської катастрофи досі турбують світову спільноту. 32014 року на Сході України проводиться антитерористична операція (АТО), там же знаходиться декілька об'єктів з відкритими джерелами іонізуючого випромінювання, окрім того, поблизу знаходиться найбільша в Європі атомна електростанція (Запорізька АЕС). Загроза злочинних діянь з використанням джерел іонізуючого випромінювання 3

\section{INTRODUCTION}

International community is still concerning about medical, social and psychological consequences of the Chornobyl disaster. Since 2014 in the East Ukraine the anti-terrorist operation (ATO) is conducting, at that place there are several sites with open sources of ionizing radiation, moreover, closely there is the Europe's largest nuclear power plant (Zaporizhska NPP). The threat of terroristic acts using ionizing radiation sources strongly rais- 
новою силою піднімає питання сприйняття радіаційної загрози та патологічних змін особистості в учасників радіаційних надзвичайних ситуацій і в осіб, які беруть участь в АТО.

Психогенний вплив екстремальних подій складається не тільки з прямої, безпосередньої загрози життю людини, але й опосередкованої, пов'язаної з очікуванням іiї реалізації. Можливість виникнення і характер психогенних розладів залежать від багатьох факторів, в тому числі від характеристик екстремальної події (iї інтенсивності, раптовості виникнення, тривалості дії), від готовності людей до діяльності в несприятливих умовах, які визначаються особистісно-типологічними якостями $[1,2]$.

Відсутність сенсорного сприйняття іонізуючого випромінювання створює когнітивний дисонанс у постраждалих в результаті радіаційних надзвичайних ситуацій, що призводить до гіпертрофованої оцінки радіаційної небезпеки [3-5]. Хронічний стрес, який виникає в результаті недостатності знань про іонізуючу радіацію та очікування віддалених наслідків іiі впливу на здоров'я, може призводити до патологічних змін особистості у населення, постраждалого в результаті радіаційних надзвичайних ситуацій. В післяаварійні роки після Чорнобильської катастрофи були відокремлені різні типи патологічного розвитку особистості, зокрема посттравматичний стресовий, психосоматичний, органічний, шизоїдний, тривожний, залежний, пасивно-агресивний [6-8].

До патологічної деформації особистості, за даними багатьох вчених, схильні особи з акцентуйованими характерологічними рисами особистості [9-14]. Тому визначення преморбідних рис особистості у постраждалих в результаті радіаційних надзвичайних ситуацій сприятиме прогнозуванню можливих «психічних травм» серед населення, постраждалих внаслідок радіаційних аварій, та оптимізації критеріїв професійного відбору осіб, які будуть залучені до ліквідації наслідків радіаційних аварій.

\section{META}

Визначити патологічні зміни особистості в учасників ліквідації наслідків аварії (УЛНА) на ЧАЕС і учасників АТО та надати оцінку особливостям сприйняття радіаційної загрози.

\section{ДИЗАЙН, ОБ'ЄКТ ТА МЕТОДИ ДОСЛІДЖЕННЯ}

Дизайн - поперечне та ретроспективне порівняльне дослідження. Оцінка особистості учасників АТО: до участі в АТО (ретроспективно) та на момент обстеження. Оцінка особистості УЛНА: до аварії (ретрос- es the question of radiation risks perception and personality pathological changes of radiation emergencies participants and persons involved in the ATO.

Psychogenic impact of extreme events is not only direct, immediate threat to human life, but also is indirectly related to the expectation of its realization. The possibility of occurrence and nature of psychogenic disorders depends on many factors, including the characteristics of extreme events (its intensity, sudden occurrence, duration), the willingness of people to work in adverse conditions, which are determined by personal and typological qualities [1,2].

The absence of ionizing radiation sensory perception creates a cognitive dissonance to survivors of radiation emergencies, leading to hypertrophic self-estimation of radiation hazards [3-5]. Chronic stress, which results from lack of knowledge about ionizing radiation effects and expectations of long-term effects of its impact on health leads to the pathological changes of the personality in the population affected by radiation emergencies. In the post-accidental years after the Chornobyl disaster there were separated the different types of pathological personality development, including post-traumatic stress, psychosomatic, organic, schizoid, anxious, dependent, and passive-aggressive ones [6-8].

According to the majority of scientists' opinion, those with personality accentuation are in a predisposition for personality pathological deformation [9-14]. Therefore, the estimation of premorbid personality traits of persons affected by radiation emergencies will help to predict a possible «mental trauma» of the population affected by radiation accidents and to develop the criteria of professional selection of persons to be involved in clean-up of radiation accidents consequences.

\section{OBJECTIVE}

Determination of pathological changes of personality of the clean-up workers (liquidators) of the Chornobyl accident and the participants in the ATO in Eastern Ukraine and radiation threat perception assessment.

\section{DESIGN, OBJECT AND METHODS}

Design - the cross-sectional and retrospective comparative study. Evaluation of the ATO combatants' personality before the ATO (retrospectively) and at the time of survey. Evaluation of the liquidators' per- 
пективно), одразу після аварії (ретроспективно) та на момент обстеження.

До дослідження залучено 107 УЛНА (І група) у віці на момент обстеження (M $\pm \mathrm{SD})(54,14 \pm$ $4,12)$ років, вік на момент аварії - $(26,73 \pm 4,51)$ років, дози опромінення - $(15,12 \pm 11,66)$ с3в; 78 УЛНА, які були до того ж і евакуйованими із Чорнобильської зони відчуження (II група) у віці на момент обстеження $(55,65 \pm 3,65)$ років, вік на момент аварії - $(28,21 \pm 3,37)$ років, дози опромінення - $(27,46 \pm 29,66)$ с3в; 112 евакуйованих із зони відчуження (III група) у віці на момент обстеження $(54,69 \pm 3,63)$ років, вік на момент аварії - $(26,75 \pm 3,67)$ років, дози опромінення $(5,47 \pm 2,73)$ с3в. Усі ці обстежені були з рандомізованої вибірки осіб, які знаходяться на обліку в Клініко-епідеміологічному реєстрі (КЕР) ННЦРМ. Також обстежено 62 учасники ATO (IV група) у віці на момент обстеження $(31,02 \pm 8,18)$ років, які проходили лікування і реабілітацію у відділенні радіаційної психоневрології ННЦРМ $[15,16]$.

Використовувались клінічні нейропсихіатричні і психометричні методи: опитувальник загального здоров'я (General Health Questionnaire, GHQ-28), особистісний опитувальник Г. Айзенка (Eysenck Personality Questionnaire, EPQ), методика діагностики характерологічних особливостей Г. Шмишека - К. Леонгарда, та модифікований соціально-психологічний опитувальник (Joint Study Project 1993) - «анкета небезпек». Електронні таблиці Excel 2010 (MS Windows) були використані як структура баз даних. Статистичний аналіз проведено у програмі Statistica 10.0 (StatSoft) за допомогою параметричних і непараметричних критеріїв.

\section{РЕЗУЛЬТАТИ ТА ОБГОВОРЕННЯ}

Найбільш поширеними психологічними і психоневрологічними розладами у обстежених $є$ низький рівень самооцінки здоров'я, соматоформні розлади, тривога, порушення сну, депресія, соціальна дезадаптація, посттравматичний стресовий розлад (posttraumatic stress disorder, PTSD) і нейрокогнітивний дефіцит. Алкогольна залежність була виявлена в невеликій кількості (10\%) обстежених учасників АТО, в основному зі Збройних сил України.

За результатами використання опитувальника загального здоров'я (General Health Questionnaire, GHQ-28) в УЛНА у порівнянні з учасниками АTO підвищений рівень соматизації і соціальної дисфункції. Загальна самооцінка здоров'я в УЛНА гірша, ніж в учасників АТО: $(30,19 \pm 13,93)$ vs $(24,56 \pm$ sonality before and immediately after the accident (both retrospectively), and at the time of the survey.

107 clean-up workers (liquidators) of the Chornobyl accident (the I group) aged at the time of the survey (M $\pm \mathrm{SD})-(54.14 \pm 4.12)$ years, age at the time of the accident $-(26.73 \pm 4.51)$ years, radiation doses $(15.12 \pm 11.66) \mathrm{cSv}$ were involved to the study; 78 liquidators who had been also evacuated from the Chornobyl exclusion zone (the II group) aged at the time of examination $(55.65 \pm 3.65)$ years, aged at the time of accident $-(28.21 \pm 3.37)$ years, radiation dose $-(27.46 \pm 29.66) \mathrm{cSv} ; 112$ evacuated from the exclusion zone (the III group) aged at the time of examination $(54.69 \pm 3.63)$ years, age at the time of accident $-(26.75 \pm 3.67)$ years, radiation doses $(5.47 \pm 2.73) \mathrm{cSv}$. All those surveyed were the randomized sample of individuals registered in the Clinical and Epidemiological registry (CER) of NRCRM. There were also examined 62 ATO combatants (the IV group) aged at the time survey as $31.02 \pm 8.18$ who underwent treatment and rehabilitation in the Department of Radiation Psychoneurology of NRCRM [15, 16].

The neuropsychiatric clinical and psychometric methods as General Health Questionnaire, GHQ-28; Eysenck Personality Inventory, EPI; method of personality diagnostic by H. Schmischek - K. Leongard, and modified social-psychological questionnaire (Joint Study Project 1993) - «dangers questionnaire» were used. Excel 2010 spreadsheets (MS Windows) were used as the database structure. Statistical analysis was performed in the program Statistica 10.0 (StatSoft) using parametric and non-parametric criteria.

\section{RESULTS AND DISCUSSION}

The most common psychological and neuropsychiatric disorders in the patients are low health self-estimation, somatoform disorders, anxiety, sleep disorders, depression, social maladjustment, posttraumatic stress disorder (PTSD) and neurocognitive deficit. Alcohol dependence was found in a small number (10\%) surveyed ATO participants, mainly from the Armed Forces of Ukraine.

As a result of the use of the General Health Questionnaire (GHQ-28), the clean-up workers compared with the ATO participants have elevated levels of somatization and social dysfunction. The total health self-estimation in the clean-up workers worse than in the ATO participants (30.19 \pm 


\section{Таблиця 1}

Самооцінка здоров'я за GHQ-28 в УлнA (I група) та бійців ATO (IV група)

Table 1

Health selfestimation by GHQ-28 in liquidators (I group) and ATO combatants (IV group)

\begin{tabular}{lcc}
\hline \hline \multirow{2}{*}{ Шкали / Scales } & $\begin{array}{c}\text { УЛНA, I група } \\
\text { Liquidators, I group }\end{array}$ & $\begin{array}{c}\text { Учасники ATO, IV група } \\
\text { ATO combatants, IV group }\end{array}$ \\
\cline { 2 - 3 } $\begin{array}{l}\text { GHQ-A } \\
\text { (соматичні симптоми/somatic symptoms) }\end{array}$ & $\mathbf{( M ~ \pm ~ S D ) ~}$ & (M \pm SD) \\
\hline $\begin{array}{l}\text { GHQ-B } \\
\text { (тривога й неспання/anxiety \& insomnia) }\end{array}$ & $10,00 \pm 4,53^{\star \star}$ & $7,53 \pm 4,88$ \\
\hline $\begin{array}{l}\text { GHQ-C } \\
\text { (соціальна дисфункції/social dysfunction) }\end{array}$ & $7,40 \pm 5,03 \pm 6,05$ \\
\hline $\begin{array}{l}\text { GHQ-D } \\
\text { (тяжка депресія/severe depression) }\end{array}$ & $9,07 \pm 3,02^{\star \star \star}$ & $7,09 \pm 2,66$ \\
\hline GHQ-28 загальний бал/GHQ-28 total scale & $3,66 \pm 5,37$ & $2,81 \pm 3,45$ \\
\hline
\end{tabular}

Примітка. Вірогідність розбіжностей: * $-p<0,05 ;{ }^{* \star}-p<0,01 ;{ }^{* \star \star}-p<0,001$.

Note. The reliability of differences: ${ }^{*}-p<0,05 ;{ }^{* *}-p<0,01 ;{ }^{\star \star *}-p<0,001$

$14,94)$ балів, відповідно $(\mathrm{t}=2,33 ; \mathrm{p}<0,05)$, що наведено у табл. 1.

Більшість обстежених учасників АТО були добровольцями, на відміну від УЛНА на ЧАЕС, тобто учасники АТО мали волю/свободу вибору ризику (34 (55\%) та 41 (22\%), відповідно; $\left.\chi^{2}=23,45: \mathrm{p}<0,001\right)$. Більшість обстежених учасників АТО палять, на відміну від УЛНА на ЧАЕС (35 (57 \%) та 55 (30\%), відповідно; $\left.\chi^{2}=13,32: \mathrm{p}<0,001\right)$. Зовсім не вживають алкоголь лише 3 (5 \%) обстежених учасників АТО, тоді як 33 (18 \%) обстежених УЛНА взагалі не вживають спиртовмісні напої - Fisher exact test $\mathrm{p}=0,0068$. Тобто, проблема вживання і зловживання психоактивними речовинами у бійців є вкрай актуальною.

За результатами особистісного опитувальника Г. Айзенка (Eysenck Personality Inventory EPI), як після участі в ліквідації Чорнобильської катастрофи, так і після АТО зменшилася екстраверсія і зросла інтроверсія, що наведено на рис. 1.

За результатами ЕРІ, як після участі в ліквідації Чорнобильської катастрофи, так i, особливо, після АТО зріс нейротизм, що наведено на рис. 2.

Профіль особистості за опитувальником Г. Шмишека - К. Леонгарда за ретроспективною оцінкою як до участі в ліквідації наслідків аварії на ЧАЕС, так і до участі в АТО, статистично значуще не відрізнявся, що наведено на рис. 3.

Після подій профіль особистості за опитувальником Г. Шмишека - К. Леонгарда в УЛНА значно відрізнявся від учасників АТО, за рахунок переважання в УЛНА емотивності та тривожності при більшому рівні у бійців АТО екзальтації, збудливості, де-
13.93 vs $24.56 \pm 14.94$ points, respectively; $\mathrm{t}=$ 2.33; $\mathrm{p}<0.05$ ), as shown in Table 1.

The majority of the ATO participants surveyed were volunteers, unlike the liquidators at Chornobyl. Thus, the ATO participants had the significant highest risk choice freedom (34 (55\%) and $41(22 \%)$, respectively; $\left.\chi^{2}=23.45 ; \mathrm{p}<0.001\right)$. Most of the surveyed ATO participants smoke, unlike the liquidators (35 (57\%) and $55(30 \%)$, respectively; $\left.\chi^{2}=13.32 ; \mathrm{p}<0.001\right) .3$ (5\%) of surveyed ATO participants only do not consume alcohol, whereas 33 (18\%) surveyed liquidators do not take alcohol drinks - Fisher exact test $\mathrm{p}=$ 0.0068 . Thus, the problem of drinking and substance abuse in the ATO combatants is very important.

After participating in clean-up works following the Chornobyl disaster and in the ATO combatants there were extraversion decreasing and introversion increasing, according to the Eysenck Personality Inventory (EPI), which is shown in Figure 1.

Neuroticism has been increased both as a result of the Chornobyl disaster, and, especially, after the ATO, according to the EPI, which is shown in Figure 2.

Personality profile according to the questionnaire by H. Schmischek - K. Leongard on retrospective assessment as to clean-up works following the Chornobyl accident, and to participate in the ATO, no statistically significant different (see Figure 3 ).

After the events a personality profile according to the questionnaire by H. Schmischek - K. Leongard in liquidators differed from the ATO participants due to predominance of emotiveness and anxiety in liquidators at higher levels of exaltation, excitability, 


\section{КЛІНІЧНI}

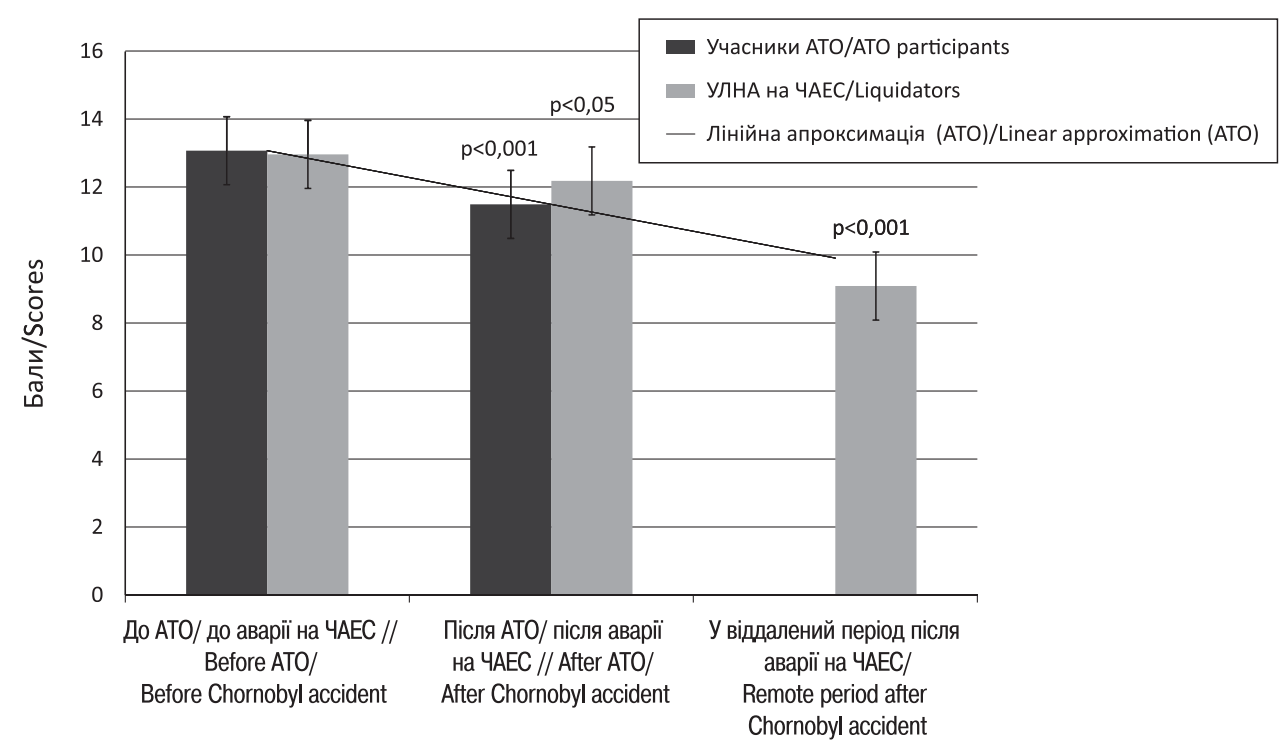

Рисунок 1. Динаміка екстраверсії/інтроверсії за особистісним опитувальником Г. Айзенка EPI (M \pm SD) у ліквідаторів (I група) та бійців ATO (IV група)

Figure 1. Follow up of extraversion/introversion by Eysenck Personality Inventory, EPI $(M \pm S D)$ in liquidators (I group) and ATO combatants (IV group)

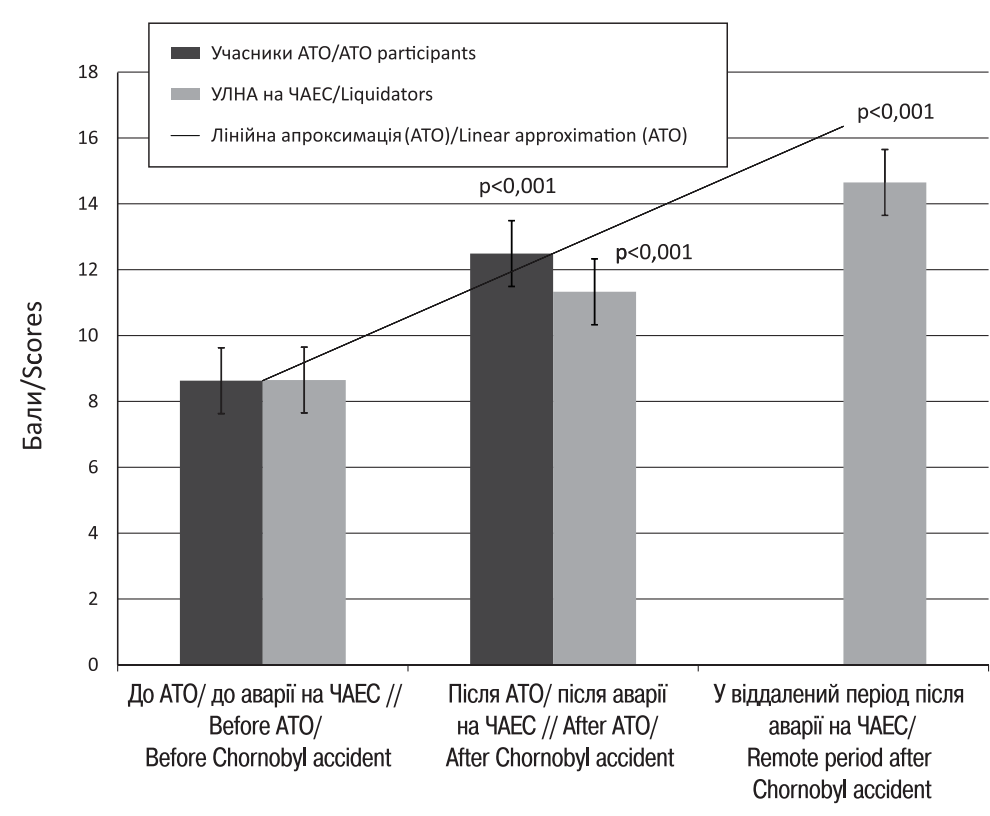

Рисунок 2. Динаміка нейротизму за особистісним опитувальником Г. Айзенка EPI (M \pm SD) у ліквідаторів (I група) та бійців ATO (IV група)

Figure 2. Follow up of neuroticism by Eysenck Personality Inventory, EPI $(M \pm S D)$ in liquidators (I group) and ATO combatants (IV group)

монстративності та гіпертимності у порівнянні 3 УЛНА, що наведено на рис. 4.

За опитувальником Г. Шмишека - К. Леонгарда виявлена суттєва деформація особистості бійців АТО за рахунок зростання таких патологічних характерологічних рис, як застрягання, педантичність, циклотимність, збудливість та дистимність, при зменшенні гіпертимності, що наведено на рис. 5. demonstrativity and hyperthymia in the ATO combatants compared to the liquidators (see Figure 4).

According to the questionnaire by H. Schmischek $\mathrm{K}$. Leongard there was detected a significant deformation of the personality of the ATO combatants due to the growth of pathological character traits as jams, pedantry, cyclothymia, excitability, and dysthymia, while hyperthymia was reduced (see Figure 5). 


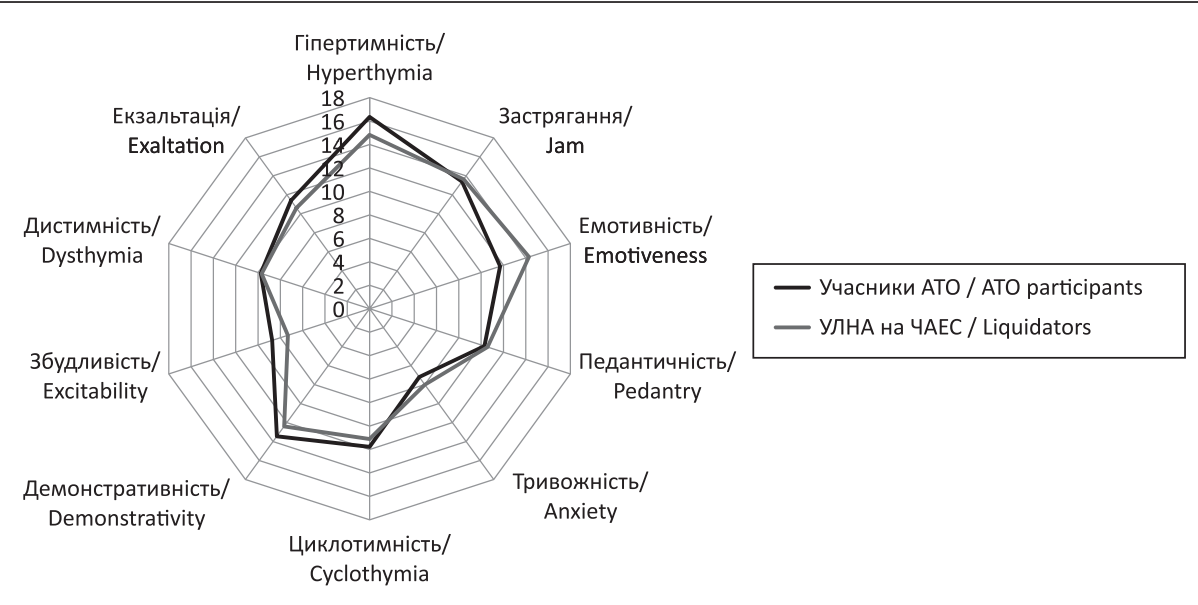

Рисунок 3. Усереднені профілі особистості до подій за опитувальником Г. Шмишека - К. Леонгарда

Figure 3. Averaged personality profile before the events according to the questionnaire by H. Schmieschek K. Leongard

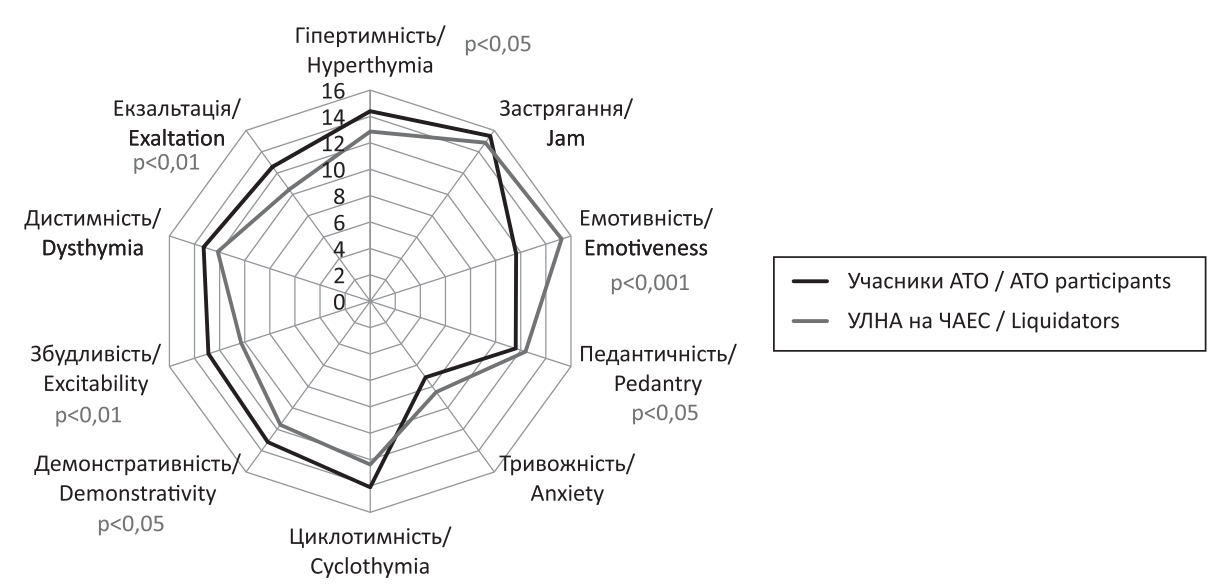

Рисунок 4. Усереднені профілі особистості після подій за опитувальником Г. Шмишека - К. Леонгарда Figure 4. Averaged personality profile after the events according to the questionnaire by $\mathrm{H}$. Schmieschek K. Leongard

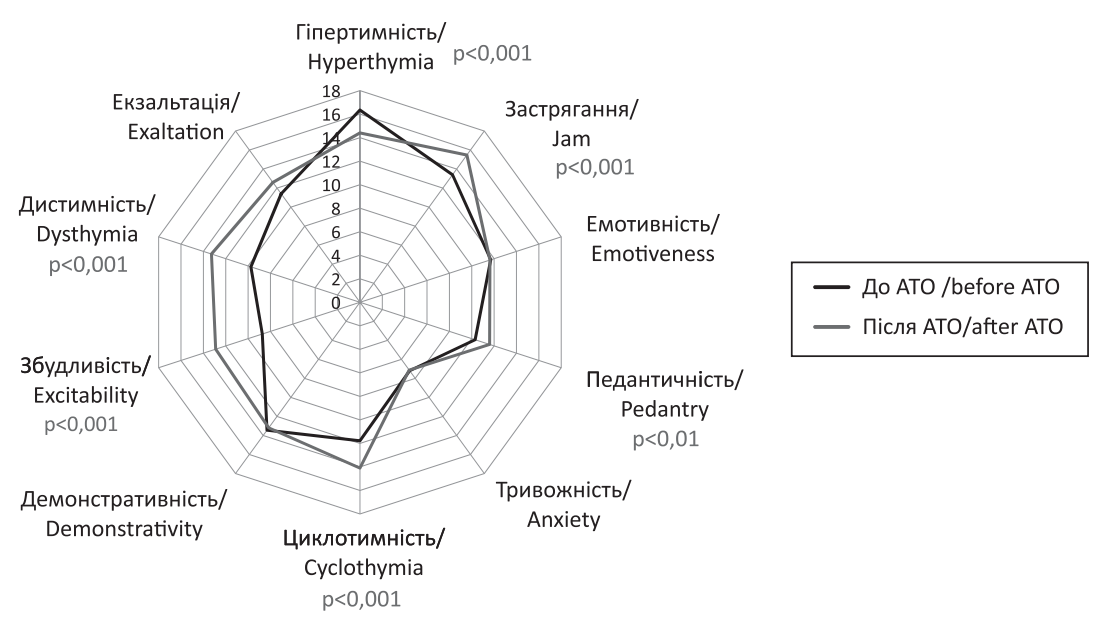

Рисунок 5. Динаміка профілів особистості учасників АТО за опитувальником Г. Шмишека - К. Леонгарда Figure 5. Follow up of personality profile of ATO combatants according to the questionnaire by H. Schmieschek - K. Leongard 
В УЛНА на ЧАЕС за опитувальником Г. Шмишека К. Леонгарда виявлена ще більша деформація особистості протягом післяаварійних років внаслідок зростання таких патологічних особистісних рис, як застрягання, емотивність, педантичність, тривожність, циклотимність, збудливість та дистимність, при зменшенні шіпертимності та демонстративності, що наведено на рис. 6.
In the clean-up workers of the Chornobyl accident according to the questionnaire by $\mathrm{H}$. Schmischek $\mathrm{K}$. Leongard there was found even greater strain identity for years after the accident due to the growth of pathological personality traits as jams, emotiveness, pedantry, anxiety, cyclothymia, excitability and dysthymia, while hyperthymia and demonstrativity were reduced, as it is shown in Figure 6.

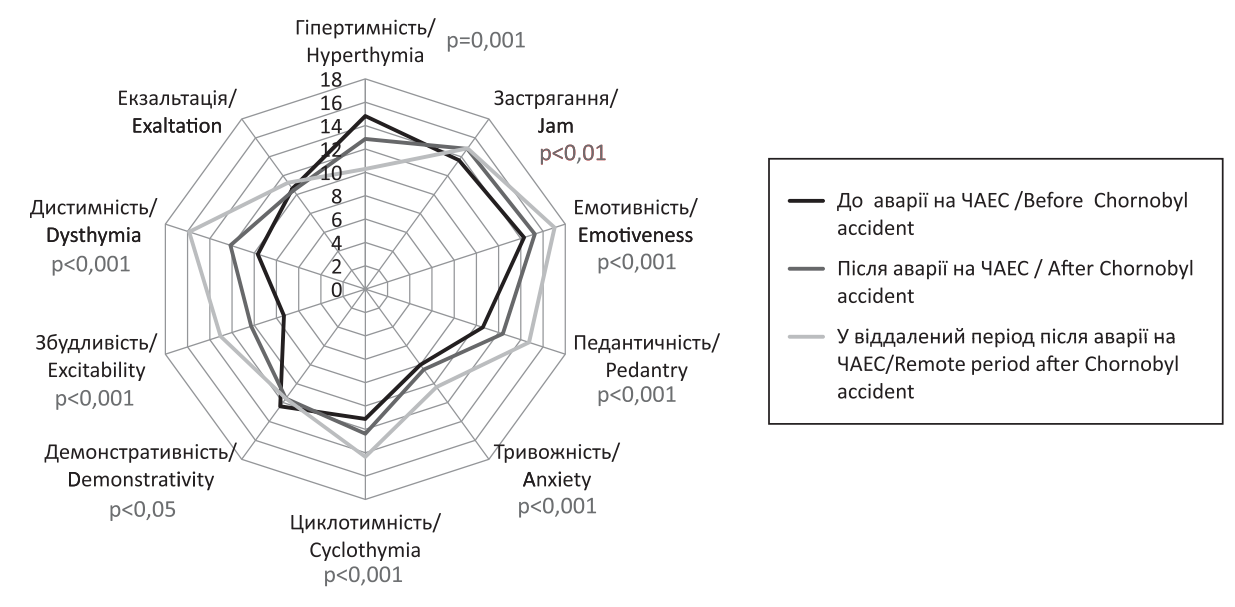

Рисунок 6. Динаміка профілів особистості УЛНА на ЧАЕС за опитувальником Г. Шмишека - К. Леонгарда

Figure 6. Follow up of personality profile of liquidators according to the questionnaire by H. Schmieschek K. Leongard

Інтегруючи отримані результати, наведені у табл. 2, в УЛНА після катастрофи зменшилися екстраверсія, гіпертимність $(\mathrm{p}<0,001)$ і демонстративність $(\mathrm{p}<$ $0,05)$ при зростанні застрягання, емотивності, педантичності, циклотимності, збудливості та дистимності (p $<0,001)$. Ці зміни з плином часу поглиблювались. На теперішній час у порівнянні з доварійним періодом (третя точка аналізу) до зазначених змін додалось достовірне зростання тривожності. Після АТО зменшилася екстраверсія і гіпертимність (р < 0,001) при збільшенні нейротизму, застрягання, педантичності, циклотимності, збудливості та дистимності ( $<<0,001)$, (табл. 2).

Динаміка змін частоти зустрічаємості акцентуацій особистості наведена у табл. 3. У порівнянні з вихідним рівнем, на момент обстеження в усіх обстежених (особливо серед УЛНА на ЧАЕС, у тому числі й УЛНА-евакуйованих) відбулася суттєва деформація особистості за рахунок зменшення екстраверсії і гіпертимності та збільшення емотивності, педантичності, тривожності, циклотимності, збудливості та дистимності.

Серед УЛНА-евакуйованих (II група) та евакуйованих (III група), як наведено у табл. 4, в другій точці достовірно зменшився рівень екстраверсії, гіпертим-
Integrating the results listed in Table 2, extraversion, hyperthymia $(\mathrm{p}<0.001)$ and demonstartivity $(\mathrm{p}<0.05)$ decreased after the disaster in the liquidators, while jams, emotiveness, pedantry, cyclothymia, excitability and dysthymia increased $(p<0,001)$. These changes deepened over time. At present (the third point analysis), compared to the pre-accident period a significant increase in anxiety to these changes added. After ATO extraversion and hyperthymia $(\mathrm{p}<0.001)$ decreased while neuroticism, jams, pedantry, cyclothymia, excitability and dysthymia increased $(\mathrm{p}<0.001)$ (Table 2).

Follow up of personality accentuation frequencies is presented in Table 3. Compared with baseline, at the time of the survey in all the patients (especially among clean-up workers, including liquidatorsevacuees) a significant deformation of the personality has occurred by reducing of extraversion and hyperthymia and increasing of emotiveness, pedantry, anxiety, cyclothymia, excitability and dysthymia.

Among the liquidators-evacuees (the II group) and evacuees (the III group) (Table 4) at the second point there were significantly decreased levels of 


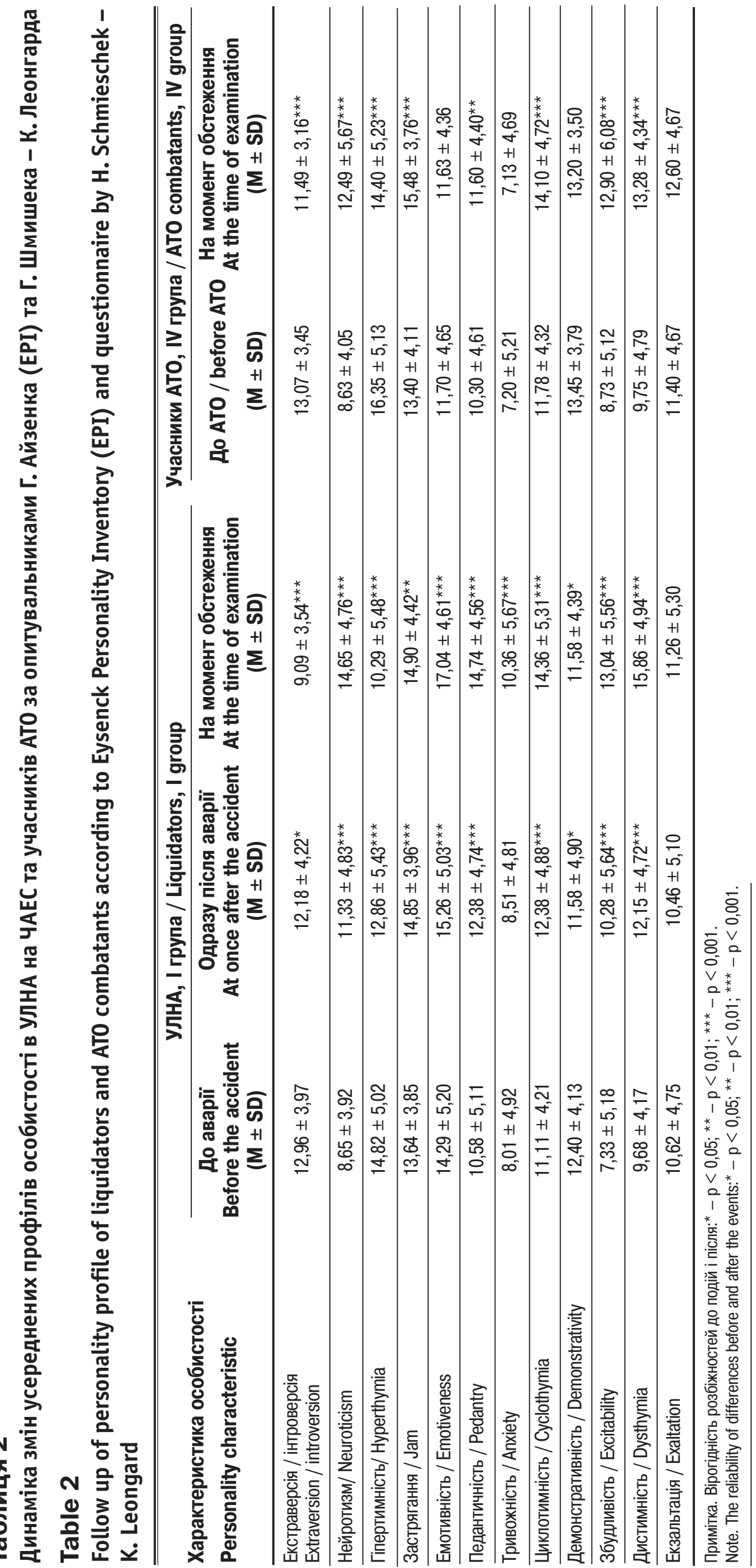




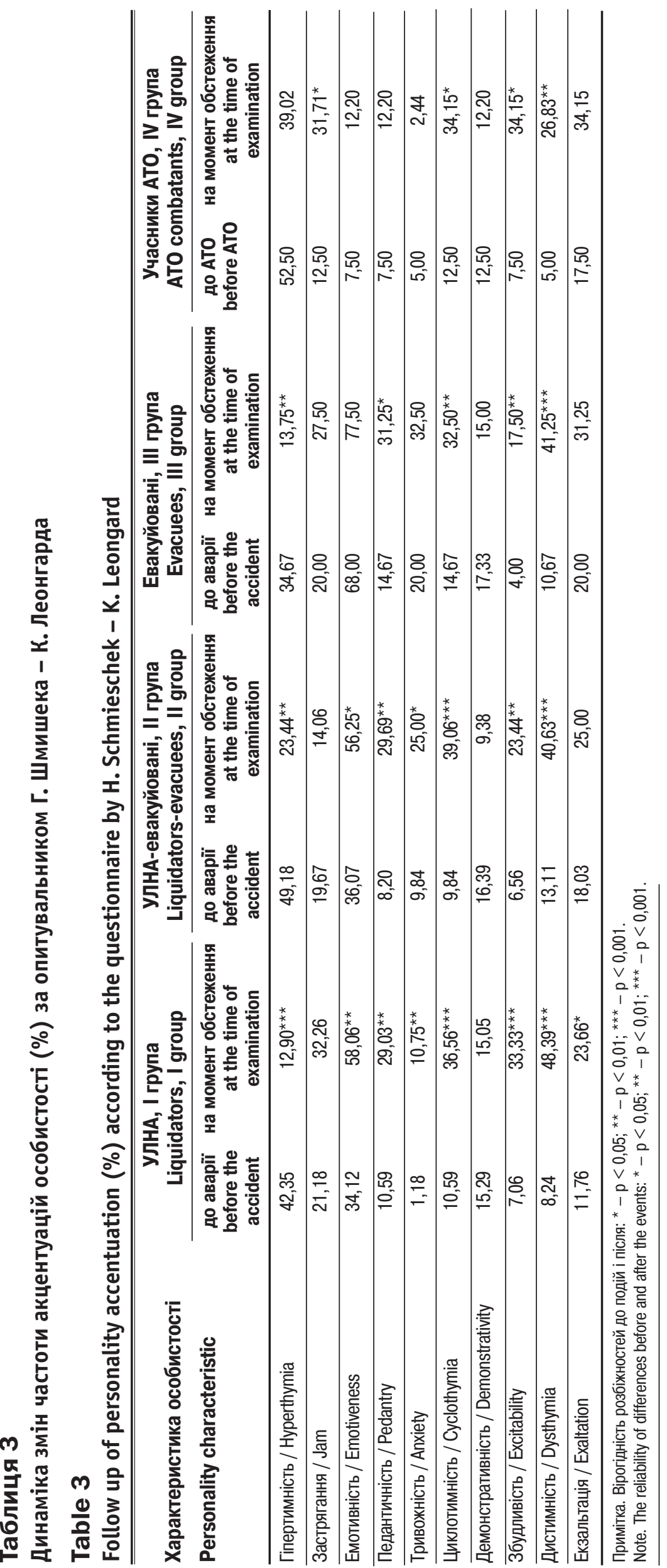




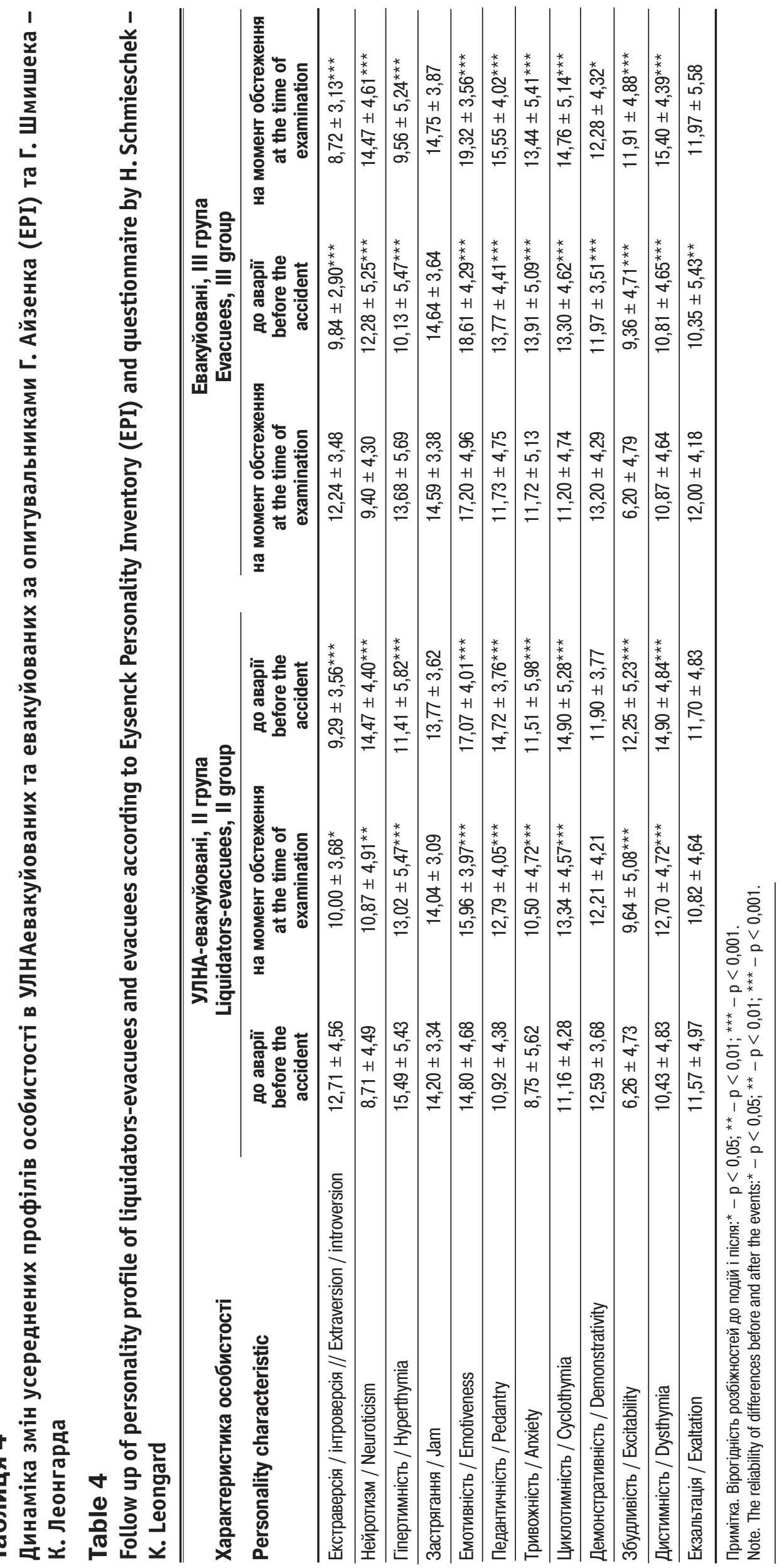


ності, демонстративності; збільшився рівень нейротизму, емотивності, педантичності, тривожності, циклотимності, збудливості, дистимності та екзальтаціі. В третій точці аналізу зазначені зміни збереглись по всіх шкалах окрім екзальтаціі.

Одержані дані свідчать про суттєві інтрапсихічні зміни серед постраждалих внаслідок Чорнобильської катастрофи та участі в АТО, які з плином часу лише поглиблюються. Стресогенним та психотравматичним для постраждалих були сприйняття соціальних ризиків, іонізуючої радіації, евакуації та війни. Особистісне сприйняття загрози - чинників ризику (радіаційних, соціально і посттравматично-стресоваих та ін.), різка зміна всього способу життя, соціально-побутових умов, характеру професійної діяльності, порушення соціальних зв'язків, які склались за багато років - все це спричинило дестабілізуючий вплив на адаптацію особистості.

У структурі соціально-психологічного опитувальника респондентам була запропонована «Анкета оцінки небезпек», де опитувані оцінювали рівень небезпеки для них та їхніх сімей серед екологічних, побутових, соціально-економічних факторів Як видно 3 табл. 5, найбільш актуальними є соціально-економічні та екологічні чинники ризику.

Водночас, сприйняття ризику національних конфліктів в учасників АТО зайняло 11-те місце (УЛНА - 22-ге), хвороб внаслідок опромінення - 5-те (УЛНА - 8-ме), атомної промисловості - 18-те (УЛНА - 12-те). Гіпертрофоване сприйняття радіаційної загрози в групах УЛНА та евакуйованих із зони відчуження корелює з підвищенням занепокоєння з приводу атомної промисловості, наявністю радіоактивних речовин у повітрі, грунті, харчах, хвороб, пов'язаних з наявністю в навколишньому середовищі радіоактивних речовин $(\mathrm{p}<0,001)$. Неадекватне сприйняття радіаційного ризику корелює і зі ступенем психологічного стресу від Чорнобильської катастрофи (в усіх групах $\mathrm{p}<0,001)$, ступенем психологічного стресу від евакуації (II група $\mathrm{p}<0,001$, III група $\mathrm{p}<0,01)$, занепокоєнням з приводу можливих аварій і несправностей у даний час на ЧАЕС (I та II група $\mathrm{p}<0,001$, III група $\mathrm{p}<0,05)$; із занепокоєнням щодо впливу радіації у зв'язку з Чорнобильською катастрофою на здоров'я ( $<<0,001)$, соціальними змінами у зв'язку з аварією ( $\mathrm{p}<0,001)$ та негативними змінами в економічній ситуації у зв'язку 3 аварією на ЧАЕС $(\mathrm{p}<0,001)$.

Під час анкетування на питання: «Чи з'явились у вас або членів вашої родини серйозні захворювання внаслідок Чорнобильської аварії?» в I групі 67 з 97 (69,07 \%) осіб відповіли - «так, у мене», в II extraversion, hyperthymia, demonstrativity; and increased levels of neuroticism, emotiveness, pedantry, anxiety, cyclothymia, excitability, dysthymia and exaltation. The third point of the analysis of these changes is preserved on all scales except exaltation.

The obtained data indicate significant intrapsychic changes among both the Chornobyl disaster survivors and ATO combatants, which only deepened with the course of time. Risk perception of social risks, ionizing radiation, evacuation and war was psychotraumatic and stressful. Personal perception of threat - risk factors (radiation, social, post-traumatic stress, et al.); an abrupt change of lifestyle, social conditions, professional activity, social relationships that have developed over the years - all this led to destabilizing impact on personality adaptation.

In the structure of the psychosocial questionnaire, respondents were offered the «dangers questionnaire» where they rated the level of danger to them and their families, including environmental, municipal, social and economic factors. As it is shown in Table 5, the most relevant are the socioeconomic and environmental risk factors.

At the same time, risk perception of national conflicts in ATO participants took the $11^{\text {th }}$ place (liquidators - the $22^{\text {th }}$ ), diseases due to radiation exposure the $5^{\text {th }}$ (liquidators - the $8^{\text {th }}$ ), the nuclear industry the $18^{\text {th }}$ (liquidators $-12^{\text {th }}$ ). Hypertrophic radiation threat perception in liquidators and evacuees from the exclusion zone correlates with increasing concern about the nuclear industry, the presence of radioactive substances in air, soil, food, diseases associated with the presence in the environment of radioactive materials $(p<0.001)$. Inadequate perception of radiation risk correlates also with the degree of psychological stress related to the Chornobyl disaster (in all groups $-\mathrm{p}<0.001$ ), the degree of psychological stress of evacuation (the II group $-p<0.001$, the III group $-p<0.01$ ), concern about possible accidents and malfunctions currently at Chornobyl NPP (the I and II groups $-p<0.001$, the III group $-p<$ 0.05 ); with concern about the effects of radiation due to the Chornobyl disaster on the health $(\mathrm{p}<0.001)$, social changes due to the accident $(\mathrm{p}<0.001)$ and negative changes in economic conditions due to the Chornobyl accident $(\mathrm{p}<0.001)$.

Answering the question: «Do you or your family have serious illness as a result of the Chornobyl accident?» in the I group 67 of 97 (69.07\%) patients responded: «Yes, I do have», in the II group -47 of 63 (74.60\%), in the 


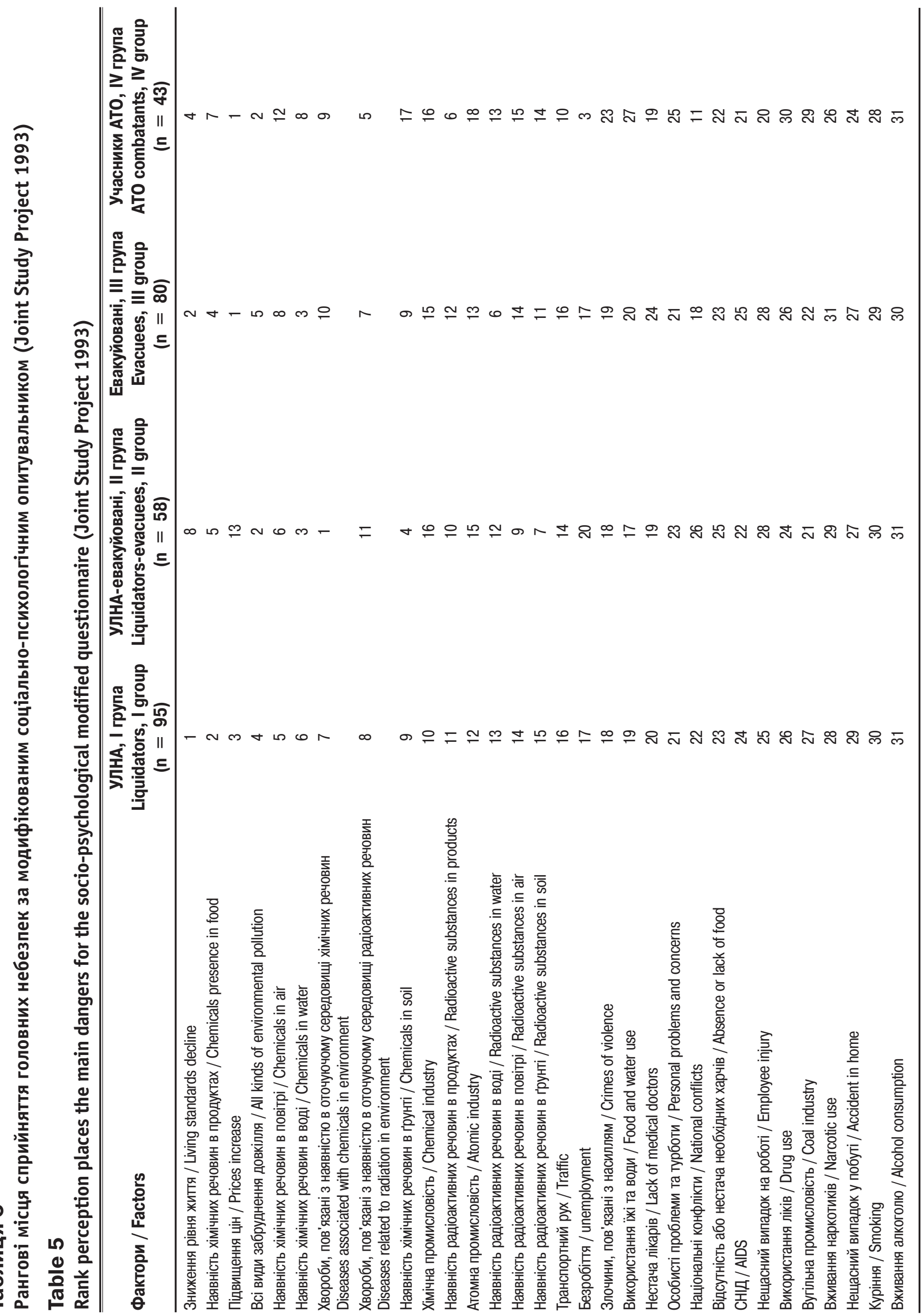


групі - 47 з 63 (74,60\%), в III групі - 54 з 77 (70,13 $\%)$. Однак на питання: «В якому ступені ви довіряєте компетенції людей, які вивчають вплив Чорнобильської аварії на здоров'я?» в I групі 53 з 98 (54,08 \%) осіб відповіли - «достатньо», в II групі - 34 з 66 (51,52 \%), в III групі - 46 з 79 (58,23\%). Але 64 з 96 (66,67\%) осіб І групи зовсім не впевнені в тому, що зможуть захистити себе та свою сім'ю від можливого радіоактивного забруднення, в II групі - 35 з 64 (54,69 \%), 3-й групі - 48 з 80 $(60,00 \%)$. Гіршим наслідком атомної аварії в I групі вважають ризик для здоров'я - 50 з 98 (51,02 $\%)$, в II групі - 29 з 65 (44,62 \%), в III групі - 42 з 82 (51,22 \%). Фінансову компенсацію, виплачувану в зв'язку з Чорнобильською аварією, 81 з 88 респондентів $(92,05 \%)$ у I групі вважають не адекватною, 51 з 64 (76,69 \%) - в II групі та 54 з 79 $(68,35 \%)$ в III групі.

Покращити ситуацію, спричинену Чорнобильською катастрофою, на думку всіх груп постраждалих, можуть центральна влада та спеціалісти з радіації, а піклуватись про людей має центральна влада, лікарі та самі люди. Соціальну реабілітацію в уражених районах в першу чергу у вигляді покращення медичного обслуговування уявляють собі постраждалі всіх груп, на другому місці в I і II групах більш високі фінансові компенсації, тоді як у III групі вона займає лише четверте місце. Повне знезараження на третьому місці в усіх групах УЛНА та евакуйованих із зони відчуження, а розвиток спеціальних інститутів, які надають соціальну і психологічну допомогу, в I та II групах на четвертому місці, а в III групі на другому місці.

Фрустрованість та стан хронічного стресу демонструють відповіді про стан звичайного самопочуття серед УЛНА та постраждалих від аварії на ЧАЕС та учасників АTO. Переважають такі почуття як: I група втомлений, зайнятий, хворий, роздратований, оптимістичний; II група - втомлений, оптимістичний, тривожний, зайнятий, хворий; III група - втомлений, тривожний, зайнятий, напружений, оптимістичний.

Учасникам ATO теж було запропоновано заповнити соціально-психологічний опитувальник. Респонденти IV групи вважають, що турбуватись про людей, постраждалих в результаті бойових дій, в першу чергу мають центральна влада $(66,07 \%)$, також місцева влада $(10,71$ $\%)$ і сім'я з друзями $(8,93 \%)$. Соціальну реабілітацію учасники АТО вбачають у відтворенні попереднього способу життя $(38,78 \%)$ і розвитку інститутів, які надають соціальну та психологічну допомогу $(24,49 \%)$. Вони не довіряють компетенції осіб, які відповідають за
III group - 54 of $77(70.13 \%)$. However, the question: «In what degree do you trust the competence of people who are studying health effects of the Chornobyl accident?» in the I group 53 of $98(54.08 \%)$ patients responded: «enough», in the II group - 34 of 66 (51,52 $\%)$, in the III group - 46 of 79 (58.23\%). However, 64 of $96(66.67 \%)$ patients in the I group were not sure they can protect themselves and their families from possible radioactive contamination, in the II group 35 of $64(54.69 \%)$, in the III group - 48 of 80 (60.00 $\%)$. The worst consequence of a nuclear accident in the I group they consider the health risk: 50 of 98 (51.02\%) in the II group - 29 of 65 (44.62 \%), in the III group 42 of $82(51.22 \%)$. Financial compensation paid in connection with the Chornobyl accident, 81 of 88 respondents $(92.05 \%)$ in the I group consider as not appropriate, 51 of $64(76.69 \%)$ in the II group and 54 of $79(68.35 \%)$ in group III, as well.

In opinion of the all examined affected groups the situation caused by the Chornobyl disaster can be improved by central government and radiation experts, and the survivors should be cared by central government, medical doctors and people themselves. Social rehabilitation in affected areas primarily in the form of improved health care all affected groups imagine, in the second place in the I and II groups is higher financial compensation, while in the III group it takes only the fourth place. Complete decontamination takes the third place in all groups of liquidators and evacuees from the exclusion zone, and the development of special institutions that provide social and psychological support for the I and II groups takes the fourth place, and in the III group - the second place.

Frustration and chronic stress are the state of current health/selfestimation of liquidators, evacuees and ATO combatants according to their answers. These feelings are dominating as follows: the I group - tired, busy, sick, angry, optimistic; the II group - tired, optimistic, anxious, busy, sick; the III group - tired, anxious, busy, tense, optimistic.

The ATO combatants were also asked to fill out a socio-psychological questionnaire. The respondents of the IV group believe that the central government (66.07\%), local government (10.71\%), family and friends $(8,93 \%)$ should care people affected by fighting. The previous lifestyle restoration $(38.78 \%)$ and the development of institutions that provide social and psychological support $(24.49 \%)$ are considered by the ATO participants as their social rehabilitation. They do not trust to 
події на Сході України (46,34 \%), при цьому доволі сильно занепокоєні майбутнім $(48,84 \%)$. Більшість 3 них $(51,16 \%)$ досить сильно були стурбовані вперше, коли дізнались про бойові дії на Сході України і 48,84 \% 3 опитаних непокояться й зараз з приводу затяжного військового конфлікту на території України. Доволі сильно їх турбують соціальні зміни $(37,21 \%)$ і негативні економічні зміни (46,51 \%), які виникли в зв'язку з бойовими діями на Сході країни. При цьому найгіршим варіантом бойових дій в першу чергу називають ризик для здоров'я $(37,21 \%)$, невпевненість у майбутньому $(11,63 \%)$ та соціальне руйнування $(11,63$ \%). Відокремлювана учасниками АТО надмірна занепокоєність $(30,00 \%)$ та недоброзичливість інших $(25,00 \%)$, як негативний наслідок бойових дій, також роблять свій внесок у рівень психологічного стресу, який вони відчувають через бойові дії на Сході країни.

Вторинної травматизації зазнають учасники АТО й після повернення додому під час намагань отримати документи, які підтверджують їхній статус та дають право на медичні і соціальні пільги. Суспільство відокремлюється від учасників АТО, адже вони повертаються в суспільство «іншими», не схожими на решту людей. При цьому відбувається фрустрація потреби у визнанні їхніх заслуг, потреби в опорі та емоційній підтримці. Для учасників АТО характерне відчуття нездатності до діяльності, відчай або безнадійність, роздратованість і спалахи гніву, епізоди агресивної поведінки, послаблення взаємозв'язків з іншими людьми, різке негативне ставлення до соціальних інститутів, до уряду; соціальна дезадаптація, яка проявляється у руйнуванні дружніх та сімейних зв'язків, втраті здатності до систематичної професійної діяльності, бажання підтримувати контакти тільки з людьми, які пережили аналогічну травматичну подію. Потреба знизити рівень фрустрації і порушення соціальних зв'язків сприяють підвищеному ризику розвитку алкоголізму та наркоманії.

Тобто, в УЛНА на ЧАЕС, евакуйованих із зони відчуження та учасників АТО виявлені ознаки деформації особистості, погіршання психічного здоров'я і підвищене сприйняття радіаційного ризику, що потребує комплексної біопсихосоціальної корекції.

\section{ВИСНОВКИ ТА ПЕРСПЕКТИВИ}

1. Довготривалі та стійки порушення психічного здоров'я, включаючи деформацію особистості, як УЛНА на ЧАЕС та евакуйованих із Чорнобильської зони відчуження, так і учасників АТО, потребують the competence of those responsible for the events in Eastern Ukraine (46.34 \%), while quite strongly concerned about the future $(48.84 \%)$. The most of them $(51.16 \%)$ were quite concerned about the first time learned of the fighting in Eastern Ukraine and $48.84 \%$ of the respondents are concerned on protracted military conflict in Ukraine. They are quite hard disturbed by social (37.21\%) and adverse economic changes $(46.51 \%)$, related to the war in the east. The worst aftermath of the war they consider health risk (37.21\%), uncertainty about the future $(11.63 \%)$, and social destruction $(11.63 \%)$. An excessive concern (30.00\%) and ill of others $(25.00 \%)$ as a negative consequence of military operations, also contribute to the level of psychological stress they are experiencing because of the fighting in the East.

The secondary traumatic experience the ATO combatants are receiving after returning home during attempts to obtain documents confirming their status and they are entitled to medical and social benefits and insurance. The society is turning off from the ATO participants, as they return to the society like «others» and do not like other people. This results in the combatant's frustration concerning their necessary to be recognized and to understand their achievements and needs in the resistance and emotional support. The ATO participants have feelings of inability to work, despair or hopelessness, irritability and outbursts of anger, episodes of violent behavior, weakening relationships with other people, negative attitude to social institutions to the government, social exclusion, which manifests itself in the destruction of friendship and family relationships, loss of capacity for systematic professional activities, as well as desire to maintain contact only with people who have experienced the similar traumatic event. The need to reduce frustration and abuse of social connections contribute to an increased risk of alcoholism and drug addiction.

That is, in the clean-up workers and ATO combatants there were revealed the signs of personality disorders, mental health deterioration and increased perception of radiation risk, which requires complex biopsychosocial correction.

\section{CONCLUSIONS AND PROSPECTS}

1. Long-term and persistent disorders of mental health, including deformation of the personality, in the clean-up workers of the Chornobyl accident, evacuees from the Chornobyl exclusion zone, and ATO partic- 
постійного психолого-психіатричного моніторингу i відповідних біопсихосоціальних втручань.

2. Незважаючи на різний тип травматичних подій, в усіх групах спостерігаються ознаки загострення характерологічних рис особистості і збільшення кількості акцентуацій.

3. Для УЛНА та евакуйованих із Чорнобильської зони відчуження характерна соціальна пасивність, інертність, емоційна лабільність, дезадаптованість, виражена чутливість, схильність до дратівливості, відчуття соціальної незахищеності, соматична стурбованість.

4. В учасників АТО відбувається формування фрустраційного патологічного розвитку особистості, яке об'єднує соціально-стресові, посттравматичні стресові та психосоматичні розлади.

5. У сприйнятті ризиків як в учасників АТО, так і в УЛНА домінують соціально-екологічні фактори, причому серед бійців АТО сприйняття радіаційних ризиків вище, ніж в УЛНА на ЧАЕС.

6. Необхідна оптимізація надання медико-психологічної та соціальної допомоги як УЛНА на ЧАЕС, так і учасникам АТО. Враховуючи збільшення кількості акцентуацій в УЛНА протягом 30-річного періоду після аварії на ЧАЕС можна припустити, що за відсутності психотерапевтичної і корекційної роботи з учасниками ATO в подальшому у них будуть спостерігатися ознаки соціальної та особистісної дезадаптації.

7. Добровільна участь у військових і надзвичайних ситуаціях є захисним фактором проти психоневрологічних розладів.

8. Потрібні наукові дослідження для визначення предикторів та біомаркерів психічних порушень при надзвичайних ситуаціях для оптимізації відбору стресостійких осіб

9. Реалізація запропонованих підходів стане суттєвим і конкретним кроком назустріч збереженню психічного здоров'я постраждалих внаслідок Чорнобильської катастрофи та учасників АТО, біженців та мігрантів з Донбасу, а тому - зміцненню обороноспроможності і безпеки держави.

\section{СПИСОК ВИКОРИСТАНОЇ ЛІТЕРАТУРИ}

1. Александровский Ю. А. Пограничные психические расстройства : руководство для врачей / Ю. А. Александровский. - Ростов-на-Дону: Феникс, 1997. - 576 с.

2. Напреенко А.К. Психическая и поведенческая дезадаптация вследствии конфликтных и кризисних социальных ситуаций / А. К. Напреенко, Т. Е. Марчук // Материалы первой науч.-практ. конф. «Манипулятивные стратегии в политике, экономике, бизнесе и методы противодействия». - Киев, 2001. - С. 182-194. ipants, need constant psychological and psychiatric monitoring and related biopsychosocial interventions. 2. Despite the different type of traumatic events, in all groups there are the signs of exacerbation of character traits and an increasing of the rate of personality accentuation.

3. Social passivity, inactivity, emotional lability, maladjustment, expressed sensitivity, tendency to irritability, a sense of social insecurity, and somatic concern are typical for liquidators and evacuees from the Chornobyl exclusion zone.

4. The pathological personality development of frustration, that integrates social-stress, post-traumatic stress and psychosomatic disorders is recognized in ATO participants.

5. The social and environmental risk factors perception are dominating in both liquidators and the ATO combatants, while radiation risks perception is higher in the ATO participants vs. the clean-up workers.

6 . There is a need of improvement of medical, psychological and social care as for the liquidators, as well as for the ATO participants. Taking into account the increasing rate of accentuation in the clean- up workers during the 30-year period after the accident, it is possible to suggest that an absence of psychotherapeutic and psycho-corrective work with ATO participants in the future will be realised in social and personal maladjustment.

7. Voluntary participation in military and emergency situations is a protective factor against neuropsychiatric disorders.

8. There is a need of researches to determine the biomarkers and predictors of mental disorders during emergency situations to optimize the selection of stress-resistant persons.

9. Implementing the proposed approach will be a significant and concrete step towards the mental health care of the Chornobyl disaster survivors and ATO combatants, refugees and migrants from Donbas, and because to strengthening the defensive potentialities and security.

\section{REFERENCES}

1. Alexandrovsky YuA. [Borderline mental disorders: a guide for physicians]. Rostov-on-Don: Phoenix; 1997. 576 p. Russian.

2. Napryeyenko AK, Marchuk TYe. [Mental and behavioral maladjustment as a result of conflict and crisis social situations]. In: Proceedings of the first scientific-practical. conference «Manipulative strategies in politics, economics, business, and methods of counteraction». Kyiv; 2001. p. 182-94. Russian. 
3. Bromet E. J. Emotional consequences of nuclear power plant disasters / E. J. Bromet // Health Phys. - 2014. - Vol. 106, no. 2. - P. 206-210.

4. Perception of risk and subjective health among victims of the Chernobyl disaster / J. M. Havenaar, E. J. de Wilde, J. van den Bout, B. M. DrottzSjoberg, W. van den Brink // Soc. Sci. Med. - 2003. - Vol. 56, no. 3. - P. 569-572.

5. Логановський К. М. Психологічні і нейропсихологічні ефекти іонізуючої радіації / К.М. Логановський // Новая медицина тысячелетия. 2013. - № 1. - С. 30-35.

6. Логановський К. М. Психічні розлади при дії іонізуючого випромінювання внаслідок Чорнобильської катастрофи: нейрофізіологічні механізми, уніфікована клінічна діагностика, лікування : автореф. дис. ... д-ра мед. наук : 03.00.01 і 14.00.16 / Костянтин Миколайович Логановський ; Науковий центр радіаційної медицини АМН України. - Київ, 2002. - 50 c.

7. Напреенко А. К. Система психиатрической помощи при радиоєкологических катастрофах и локальніх войнах / А. К. Напреенко, К. Н. Логановский // Журнал психиатрии и медицинской психологии. - 2000. - № 1 (7). - С. 14-18.

8. Осуховская Е. С. Клинико-психопатологические особенности расстройств личности у участников ликвидации последствий аварии на Чернобыльской АЭС в отдалённом периоде и их коррекция / Е. С. Осуховская // Арх. психіатрії. - 2003. - № 4(35). - С. 50-57.

9. Лочехина Л. И. Связь посправматического стресса с интеллектом и смысло-ценностными ориентациями [Электронный ресурс] / Л. И. Лочехина // Психологические исследования. - Электрон. науч. журн. 2010. - № 5(13). - Режим доступа: http://psystudy.ru.

10. Association between the Five Factor personality traits and perceived stress: is the effect mediated by general self - efficacy? / J. F. Ebstrup, L. F. Eplov, C. Pisinger, T. Jorgensen // Anxiety Stress Coping. - 2011. - Vol. 24, no. 4. - P. 407-419.

11. Oginiska-Bulik N. Type D personality, coping with stress and intensity of PTSD symptoms in firefighters / N. Oginiska-Bulik, I. Langer // Med. Pr. - 2007. - Vol. 58, no. 4. - P. 307-316.

12. Румянцева Г. М. Проблемы восприятия и субъективной оценки риска от ионизирующей радиации / Г. М. Румянцева, О. В. Чинкина // Радиационная гигиена. - 2009. - Т. 2, № 3. - С. 50-58.

13. Леонгард К. Акцентуированные личности : [пер. с нем.] / К. Леонгард. - Ростов н/Д : Феникс, 2000. - 544 с.

14. Сурмяк Ю. Соціально-психологічна допомога учасникам бойових дій у подоланні посттравматичного стресового розладу / Ю. Сурмяк, Л. Кудрик // Педагогіка і психологія професійної освіти. - 2015. - № 3. - С. 123-134.

15. Eysenck H. J. Manual of the Eysenck Personality Questionnaire / H. J. Eysenck, S. B. G. Eysenck. - London : Hodder and Stoughton, 1975. - 47 p. 16. Schmieschek H. Questionnaire for the determination of accentuated personalities / H. Schmieschek // Psychiatr. Neurol. Med. Psychol. (Leipz). 1970. - Vol. 22, no. 10. - P. 378-381.
3. Bromet EJ. Emotional consequences of nuclear power plant disasters. Health Phys. 2014;106(2):206-10.

4. Havenaar JM, de Wilde EJ, van den Bout J, Drottz-Sjoberg BM, van den Brink W. Perception of risk and subjective health among victims of the Chernobyl disaster. Soc Sci Med. 2003;56(3):56972.

5. Loganovsky KM. [Psychological and neuropsychological effects of ionizing radiation]. New Medicine of Millennium. 2013;(1):30-5. Ukrainian.

6. Loganovsky KN. [Mental disorders at exposure to ionizing radiation as a result of the Chernobyl accident: neurophysiological mechanisms, unified clinical diagnostic, treatment]. [Thesis of Dissertation of Dr Med Sci.]. Kyiv: Research Centre for Radiation Medicine of Academy of Medical Sciences of Ukraine; 2002. 50 p. Ukrainian, Russian.

7. Napryeyenko AK, Loganovsky KN. [The system of psychiatric care at radioecological disasters and local wars]. Journal of psychiatry and medical psychology. 2000;7(1):14-8. Russian.

8. Osukhovskaya ES. [Clinical and psychopathological features of personality disorders in clean-up workets of the Chornobyl accident in the remote period and their correction]. Arch Psychiatry. 2003;35(4):50-7.

9. Lochehyna LI. Associatilons of posttraumatic stress with intelligence and meaning-evaluation orientation. Psychological research [Electronic Scientific Journal]. 2010;13(5). Access: http://psystudy.ru.

10. Ebstrup JF, Eplov LF, Pisinger C, Jorgensen T. Association between the Five Factor personality traits and perceived stress: is the effect mediated by general self - efficacy? Anxiety Stress Coping. 2011;24(4):407-19.

11. Oginiska-Bulik N, Langer I. Type D personality, coping with stress and intensity of PTSD symptoms in firefighters. Med Pr. 2007;58(4):307-16.

12. Rumyantseva GM, Chinkina OV. [Problems of perception and subjective assessment of the risk from ionizing radiation]. Radiation Hygiene. 2009;2(3):50-8. Russian.

13. Leonhard K. Accentuated personalities: [translation from Germany]. Rostov-na-Donu: Phoenix, 2000. 544 p. Russian.

14. Surmyak Yu, Kudryk L. [Psychosocial assistance to combatants in overcoming PTSD]. Pedagogy and Psychology of Professional Education. 2015;(3):123-34. Ukrainian.

15. Eysenck HJ, Eysenck SBG. Manual of the Eysenck Personality Inventory. London: Hodder and Stoughton; 1975. 47 p.

16. Schmieschek H. Questionnaire for the determination of accentuated personalities. Psychiatr. Neurol Med Psychol (Leipz). 1970;22(10):378-81. 